\title{
ASPEK YURIDIS PASAR MODAL SEBAGAI SARANA PEMBIAYAAN DAN PENGEMBANGAN PERUSAHAAN
}

\author{
Suradiyanto \\ Suradiyanto60@gmail.com \\ Dosen Fakultas Hukum Universitas Widya Gama Mahakam Samarinda dan Dosen Fakultas Hukum \\ Universitas Mulawarman Samarinda
}

\begin{abstract}
Parties that require investment fund is not limited to the government alone, but also other productive sectors of the private sector. If the government usually acts as an initiative taker physical infrastructure development, the private sector (individuals and companies) to act as a driver of economic activity such as attempts commercial production of goods and services calculated based on pure business will be profitable. All this requires a good investment fund short-term nature, such as working capital for the cost of operational needs, as well as longterm funds such as for procurement of fixed assets required. In order to meet the needs of the company will fund as a means of financing and development can be done through various options of financing the company and one of the company's financing alternatives can be done by finding others to participate invest in the company. This can be done by selling the majority ownership of the company to the general public by way of public offering (go public) through the capital market. Initial public offerings made by the company through the capital market can make the company receives cash from the public which can then be used by the company for financing and development of the company
\end{abstract}

Keyword: Capital Markets, Financing and Corporate Development

\section{PENDAHULUAN}

\section{A. Latar Belakang}

Sebagaimana diketahui, usaha-usaha pembangunan khususnya pembangunan di bidang ekonomi yang telah dilaksanakan secara terus menerus sejak Pelita I Tahun 1969 membutuhkan dana investasi yang tidak sedikit jumlahnya. Semua dana yang terhimpun bukan saja diperuntukkan untuk pembangunan prasarana fisik bagi keperluan umum, tetapi juga untuk kegiatan yang sifatnya produktif komersial.

Pihak-pihak yang membutuhkan dana investasi tidak terbatas kepada pemerintah saja, tetapi juga sektor produktif lain dari kalangan swasta. Kalau pemerintah biasanya bertindak sebagai pengambil inisiatif pembangunan prasarana fisik, pihak swasta (perorangan dan perusahaan) bertindak sebagai penggerak kegiatan ekonomi komersial seperti usahausaha produksi barang dan jasa yang berdasarkan kalkulasi bisnis murni akan menguntungkan. Semuanya ini memerlukan dana investasi baik yang sifatnya jangka pendek, seperti modal kerja untuk biaya kebutuhan operasional, maupun dana jangka panjang seperti untuk pengadaan aktiva-aktiva tetap yang dibutuhkan.

Terdapat berbagai motivasi mengapa sektor swasta memilih pasar modal sebagai alternatif penggalian dananya, antara lain guna menekan biaya modal (cost capital), diversifikasi sumber dana, dan sebagai suatu cara untuk mengelola valuta asing 
secara lebih berhati-hati (prudent). Selain itu, pemilihan pasar modal internasional sebagai salah satu alternatif sumber pembiayaan juga didorong oleh belum cukup berkembangnya pasar modal domestik negara bersangkutan. ${ }^{1}$

Sumber dana yang diperlukan untuk mendukung derap langkah pembangunan ekonomi tersebut dapat diperoleh melalui berbagai bentuk kelembagaan dalam bidang keuangan (financial market) berupa pasar uang dan pasar modal. Menurut Frank J. Fabozzi, "Financial market is a market where financial assets are exchange or traded, transferring fund from those who have surplus fund to invest to those who needs to invest intangible assets". ${ }^{2}$

Guna memahami peranan yang diharapkan dari pasar uang dan pasar modal dimaksud, perlu dipahami terlebih dahulu hakikat dari kedua pasar ini yang pada dasarnya adalah sebagai perantara, "intermediary", atau "channel" dari proes pengerahan dana dari individu atau lembaga yang memiliki kelebihan dana (excess of fund/supplier of fund), kepada orang atau perusahaan yang memerlukan dana (lack of fundldemander of fund), serta menggunakannya untuk kegiatan-kegiatan produktif.

Pada bagian lain Mc. Lindon mengatakan bahwa melalui pasar modal dilakukan transfer dana dari para penabung ke sektor dunia usaha guna dimanfaatkan secara jangka panjang, untuk selanjutnya ditanamkan dalam bentuk investasi fisik yang diperlukan untuk menaikkan kapasitas

${ }^{1}$ Jusuf Anwar, 2005, Pasar Modal Sebagai Sarana Pembiayaan dan Investasi, Alumni, Bandung, hlm. 114

2 Frank J. Fabozzi dan Madigliani Franco, 1992, Capital Market : Institutions and Intrument, Prentice hall Inc., A Simon \& Schuter Company Engk Wood Cliffs, New Jersey, hlm. 11 produksi guna mewujudkan pertumbuhan ekonomi. $^{3}$

Perlu diingatkan kembali bahwa pasar modal (di samping pasar uang) hanyalah salah satu alternatif jalur yang mempertemukan pihak-pihak yang ingin mendapatkan sumber-sumber dana jangka panjang (dunia usaha) dengan pihak-pihak yang bersedia menanamkan uangnya untuk tujuan tersebut (para pemodal). Namun, karena fungsi strategis pasar modal yang berperan bagi berbagai kepentingan, fungsinya menjadi demikian penting dan bahkan dijadikan sebagai salah satu barometer kemajuan dari suatu perekonomian. Cukup banyak faktor yang dapat mendorong tumbuh suburnya pasar modal Indonesia seperti besarnya potensi sektor dunia usaha untuk menjadi emiten, majunya teknologi serta adanya program pemerintah yang memerlukan adanya suatu pasar modal yang efektif dan efisien. Sebagaimana dikatakan Michael P. Mc Lindon mengenai adanya elemen yang menciptakan tumbuhnya pasar modal, yakni: ${ }^{4}$

a. Adanya kesadaran masyarakat mengenai manfaat dan peluang yang terdapat di pasat modal serta manfaat lain dari kepemilikan saham;

b. Perkembangan prasarana pasar modal seperti majunya teknologi informasi yang mendorong tumbuhnya sistem perdagangan elektronik, kliring, pendaftaran saham dan lain-lain;

c. Perkembangan peraturan perundangan guna terciptanya kepercayaan masyarakat, perlindungan pemodal dan kemandiriannya;

d. Adanya program privatisasi yang mendorong penawaran dan permintaan saham.

\footnotetext{
${ }^{3}$ Michael P. Mc Lindon, 1996, Proegen, Connecticut, hlm. 42

${ }^{4}$ Ibid, hlm. 61
} 
Ada yang mengatakan bahwa pasar modal bersaing dengan pasar uang dalam memanfaatkan tabungan masyarakat. Dikatakan oleh Michael P. Mc Lindon bahwa di dalam pasar uang diperdagangkan dana jangka pendek kurang dari 1 tahun dan mempunyai risiko kecil, tetapi tinggi likuiditasnya, sedangkan untuk investasi jangka panjang yang lebih dari 1 tahun memanfaatkan keberadaan pasar modal. Namun, sebenarnya di dalam sarana pasar modal pun terdapat persaingan yang ketat. Sebenarnyalah pasar modal bersaing satu sama lain yakni dalam rangka menarik para pemasok dana untuk dimanfaatkan oleh dunia usaha maupun pemerintah. Persaingan yang umum adalah di bidang perpajakan seperti pembebasan atas dividen ataupun atas nilai lebih (capital gain), pembebasan pajak atas komisi pialang, penentuan komisi yang tetap (fixed) dan murah, mengurangi jumlah dokumen dalam rangka transparansi dan mengurangi banyaknya jenis laporan, dilaksanakannya sistem perdagangan elektronik dan tidak rumitnya syarat pencatatan di bursa. ${ }^{5}$

Pada awal kebangkitannya, pasar modal Indonesia pun mencoba untuk menarik dan merangsang masyarakat baik masyarakat pengusaha, masyarakat pemodal maupun lembaga perantaraa agar mau terjun aktif ke pasar modal dengan menawarkan berbagai fasilitas perpajakan. Antara lain pemutihan bagi dana masyarakat yang diinvestasikan dalam pembelian sekuritas dan pembebasan bea materai modal atas kapitalisasi surplus revaluasi. Fasilitas lain adalah pembebasan pajak atas dividen, bunga, royalti atas "capital gain" yang diakibatkan devaluasi

5 John Fingleton, 1992, The Internalization of Capital Markets and the Regulatory Response, Graham \& Tratman, London, hlm. 189 dan pembebasan pajak penjualan atas komisi para pialang. ${ }^{6}$

Diantara ciri-ciri yang menarik dari pasar modal antara lain adalah kemampuannya untuk menjembatani perbedaan horison waktu dari pemodal dengan horison waktu dari perusahaan emiten. Maksudnya, adalah bahwa dari sisi perusahaan, dana yang diperoleh melalui pasar modal haruslah tersedia untuk jangka waktu yang lama, misalnya lima sampai tiga puluh tahun dalam hal obligasi atau selama umur perusahaan dalam hal saham. Namun dari sisi pemodal atau pemilik dana, jangka waktu kesediaannya meminjamkan uang sangat beragam, ada yang sangat singkat misalnya 6-12 bulan, ada untuk jangka waktu menengah 1-5 tahun, dan ada juga yang berjangka waktu lama.

Dengan demikian, faktor periode waktu yang masing-masing pihak bersedia menenamkan dana dan atau menginginkan dana disebut dalam suatu kurun waktu tertentu, maka pasar modal berperan menjembatani perbedaan horison waktu tersebut, yakni antarta keperluan modal bagi perusahaan yang berjangka waktu panjang dengan horison pemilik uang yang sangat beragam periode waktunya. Hal ini dilaksanakan dengan menciptakan dan menjaga likuiditas dari surat-surat berharga (saham atau obligasi) yang diperdagangkan melalui pasar modal.

Berkaitan dengan hal tersebut, para pemodal atau pemegang surat berharga dapat membeli dan menjual efek yang dimilikinya setiap saat sesuai dengan kebutuhannya, sementara pihak perusahaan yang menerbitkan (emiten) surat berharga tersebut tidak perlu harus mengembalikan dana yang telah digunakannya setiap satu atau sekelompok pemodal memerlukan kembali uangnya. Dengan perkataan lain,

6 Jasso Winarto (ed) 1997, Pasar Modal Indonesia, Pustaka Sinar Harapan, Jakarta, hlm. 34 
efek-efek dapat berpindah tangan dari satu pemodal kepada pemodal lainnya tanpa harus mengganggu likuiditas perusahaan emiten.

Interaksi pembeli dana dan penjual dana dalam pasar keuangan (financial market) menciptakan harga dari efek yang diperdagangkan, dimana suatu financial market menciptakan likuiditas. Tanpa adanya likuiditas tersebut, pemilik efek bersifat hutang akan menahan efeknya sampai jatuh tempo, sedangkan terhadap efek penyertaan (equity securities) akan tertahan hingga saat perusahaan penerbit efek tersebut dilikuidasi.

Sebagaimana telah disinggung sebelumnya, pasar modal dapat dibedakan dalam dua kategori yaitu pasar primer atau perdana (primary market) dan pasar sekunder (secondary market). Pasar primer adalah pasar dimana perusahaanperusahaan emiten menawarkan efek secara langsung kepada calon pemodal untuk pertama kalinya di pasar perdana selama jangka waktu tertentu. Proses penawaran efek pada pasar primer dilakukan setelah pernyataan pendaftaran untuk melakukan penawaran umum efek tersebut mendapat pernyataan efektif dari Bapepam. Selanjutnya, akan dilalui suatu proses tahapan yang meliputi antara lain pengumuman dan pendistribusian prospektus, masa penawaran, masa penjatahan dan pengembalian dana dalam hal pesanan efek pencatatan efek di bursa efek atau di pasar sekunder.

Pasar sekunder adalah pasar dimana pemodal memperjual belikan efek-efek yang dimilikinya kepada pemodal lainnya. Pasar sekunder umumnya dilakukan di bursa efek, tetapi dapat pula terjadidi luar bursa efek. Pasar sekunder diciptakan untuk memberi kesempatan kepada pemodal yang telah mempunyai efek untuk memperjual belikan kembali efeknya, atau memberi kesempatan kepada pihak yang belum memperoleh efek di pasar pasar perdana.

Sejalan dengan pendapat itu, Meir Kuhn mengatakan pula bahwa pasar modal merupakan wahana jual beli surat berharga. Pasar dimana surat berharga yang baru dijual disebut sebagai pasar perdana sedangkan pasar dimana surat berharga yang sudah ada dijual disebut sebagai pasar sekunder. Pendapat yang sama mengenai pengertian pasar perdana dan pasar sekunder tersebut dikemukakan juga oleh Michael P. Mc Lindon. ${ }^{7}$

Semua mekanisme pembentukan harga baik pada pasar primer maupun pada pasar sekunder mengikuti mekanisme permintaan dan penawaran pasar (demand and supply merchanism of the market). Artinya bahwa untuk efek tertentu yang jumlah permintaannya melebihi jumlah yang ditawarkan untuk dijual (over subscription), antara lain karena kinerja perusahaan emiten yang semakin baik misalnya harga efek tersebut akan cenderung menaik. Sebaliknya untuk efek yang jumlah penawaran untuk dijual melebihi jumlah permintaan (undersubscription) antara lain yaitu karena memburuknya, harga efek tersebut akan cenderung menurun.

\section{B. Rumusan Masalah}

Berdasarkan uraian dalam latar belakang masalah tersebut di atas, maka permasalahan dalam penelitian ini adalah sebgai berikut :

a. Bagaimana peran pasar modal sebagai sarana pembangunan dan pengembangan perusahaan?

b. Bagaimana syarat yuridis dan prosedur bagi perusahaan yang akan melakukan Go Public di pasar modal? 


\section{METODE PENELITIAN}

A. Janis Penelitian

Penelitian ini merupakan penelitian hukum normatif, yaitu penelitian yang mengutamakan penelitian kepustakaan untuk memperoleh data sekunder sebagai data utamanya.

\section{B. Sumber Data}

Data dalam penelitian kepustakaan ini adalah data sekunder yang merupakan bahan-bahan hukum yang terdiri dari: ${ }^{8}$

a. Bahan Hukum Primer, yaitu bahan hukum yang bersifat mengikat yang terdiri dari:

1) Undang-Undang Dasar Negara Republik Indonesia Tahun 1945

2) Kitab Undang-Undang Hukum Perdata (KUH Perdata)

3) Undang-Undang Nomor 8 Tahun 1995 tentang Pasar Modal

4) Undang-Undang Nomor 40 Tahun 2007 tentang Perseroaan Terbatas

5) Peraturan perundang-undangan lainnya yang berhubungan dengan penelitian ini.

b. Bahan Hukum Sekunder, yaitu bahan hukum yang memberikan petunjuk serta penjelasan terhadap bahan hukum primer, yang terdiri dari buku-buku literatur, makalah, artikel, jurnal hasil penelitian, dan karya ilmiah lainnya yang berhubungan dengan penelitian ini.

c. Bahan Hukum Tertier, yaitu bahan hukum yang memberikan petunjuk dan penjelasan terhadap bahan hukum primer dan bahan hukum sekunder yang terdiri dari:

1) Kamus Umum Bahasa Indonesia

2) Kamus Hukum

3) Kamus Inggris - Indonesia

8 Soerjono Soekanto dan Sri Mamudji, 2003, Penelitian Hukum Normatif, Suatu Pengantar Singkat, PT Raja Grafindo Persada, Jakarta, hlm. 13
4) Ensiklopedia

C. Analisis Data

Data yang telah dikumpulkan baik dari penelitian kepustakaan maupun dari penelitian lapangan selanjutnya dianalisis secara kualitatif dengan metode deskriptif.

1. Deskriptif; yaitu metode analisis dengan cara menggambarkan keadaan sebenarnya di lapangan.

2. Kualitatif, yaitu metode analisis data dengan cara mengelompokkan dan menseleksi data yang diperoleh dari penelitian menurut kualitas dan kebenarannya, kemudian dihubungkan dengan teori-teori dari studi kepustakaan sehingga diperoleh jawaban atas permasalahan dalam penelitian ini.

Dalam analisis data ini digunakan cara berfikir induktif, yaitu menyimpulkan hasil penelitian dari hal yang bersifat khusus untuk kemudian diambil kesimpulan yang bersifat umum

\section{PEMBAHASAN}

\section{Peran Pasar Modal Sebagai Sarana Pembangunan dan Pengembangan Perusahaan}

Perjalanan hidup perusahaan mirip dengan perjalalan hidup manusia yang mulai dari lahir, tumbuh, berkembang, menjadi dewasa bahkan dapat pula menjadi tua dan mati. Dalam menjalani siklus hidup ini seperti layaknya manusia, perusahaan juga membutuhkan darah segar. Dalam kenyataan sehari-hari darah yang diperlukan ini berupa modal usaha yang terutama dalam bentuk uang tunai (cash).

Memang sulit untuk, disangkal bahwa modal yang dibutuhkan, apapun bentuknya pada dasarnya adalah uang. Uang yang sangat diperlukan perusahaan adalah dalam bentuk tunai yang sebenarnya bukan dalam bentuk catatan pembukuan, 
laporan keuangan, neraca, laba/rugi ataupun aliran kas/cash flow.

Banyak perusahaan yang terkecoh oleh angka-angka yang disajikan dalam laporan keuangan, tapi ternyata setelah tiba waktunya untuk melakukan pembayaran, tidak tersedia uang yang cukup di kas. Hal ini tentunya sangat tidak baik untuk perusahaan. Dan bila hal ini terjadi tentunya kegiatan perusahaan akan terganggu dan terhenti atau bahkan mungkin perusahaan akan pailit.

Modal dalam bentuk uang sangat diperlukan oleh perusahaan, selain untuk menjaga kelangsungan hidup juga untuk pengembangan usaha. Yang menjadi masalah bagi tiap perusahaan adalah dari mana uang tersebut didapat, bila uang perusahaan yang ada sedang beredar di mana-mana sesuai dengan transaksi yang dilakukan sedangkan hutang perusahaan sudah mencapai tingkat yang cukup tinggi. Bila hal ini dibiarkan berlarut-larut maka bukan tidak mungkin perusahaan akan mengalami kebangkrutan. Di samping itu selain untuk menjaga kelangsungan hidup dan mengembangkan usaha, uang juga dibutuhkan untuk berbagai keperluan termasuk untuk membayar hutang-hutang perusahaan yang ada. ${ }^{9}$

Untuk memenuhi kebutuhan dana tersebut tentunya diperlukan usaha untuk mencari tambahan uang (berupa "fresh money") untuk disuntikkan ke perusahaan, sebagai pengganti ataupun sebagai penambah dana yang sedang dijalankan ataupun untuk pengembangan dan perluasan bidang usaha.

Dalam rangka pemenuhan hal tersebut ada beberapa alternatif yang dapat digunakan perusahaan untuk mengatasinya, seperti mencari pinjaman atau tambahan pinjaman uang, mencari partner untuk

9 Asril Sitompul, 1996, Pasar Modal, Penawaran Umum dan Permasalahannya, Citra Aditya Bakti, Bandung, hlm. 11 merger, menjual perusahaan atau bahkan menutup/mengurangi sebagian kegiatan usaha, upaya tersebut terakhir tentunya tidak baik bagi perusahaan dan juga bagi pemilik dan pegawainya.

Alternatif lainnya yang dapat dilakukan dalam mencari tambahan modal itu adalah dengan mencari pihak lain yang mau ikut menanamkan modalnya pada perusahaan. Hal ini dapat dilakukan dengan menjual sebagian dari kepemilikan atas perusahaan, penjualan kepemilikan dilakukan dengan berbagai cara salah satunya adalah dengan penjualan sebagian dari saham perusahaan dalam bentuk efek kepada masyarakat luas yang dalam hal ini disebut investor atau pemodal. Hal ini dikenal dengan istilah Penawaran Umum (Go Public).

Penjualan kepemilikan modal perusahaan ini dapat pula dilakukan dalam lingkup yang teratas dengan jalan melakukan penawaran secara terbatas yang dikenal dengan istilah Privat Placement, atau dapat juga dengan menerbitkan efek yang merupakan tanda hutang seperti obligasi (dalam obligasi tidak terdapat unsur kepemilikan karena obligasi lebih merupakan tanda hutang perusahaan).

Penjualan saham oleh perusahaan yang dilakukan untuk pertama kali, disebut penawaran umum perdana atau juga Initial Public Offering (IPO), pada penjualan saham perdana inilah perusahaan akan menerima uang tunai dan keuntungan dari selisih nilai nominal saham dengan harga saham pada pasar perdana. Misalnya harga nominal saham adalah 500 rupiah sedang pada pasar perdana dijual dengan harga 2500 rupiah, maka sebenarnya perusahaan akan mendapat keuntungan sebesar 2000 rupiah per sahamnya. Namun pada prakteknya seluruh uang yang dihasilkan dari penawaran umum tersebut adalah merupakan uang segar (fresh money) yang 
dapat segera dimanfaatkan untuk berbagai keperluan perusahaan.

Beberapa hal yang menjadi alasan bagi perusahaan melaksanakan penawaran umum, selain pencarian dana sebagai pertimbangan yang paling penting, hal tersebut adalah: ${ }^{10}$

a. Meningkatkan kepemilikan saham bagi pemodal retail

b. Menjual sebagian kepemilikan atas perusahaan

c. Mencari proceed yang sebesarbesarnya

d. Menciptakan dasar bagi distribusi yang berlingkup internasional (untuk penawaran di luar negeri)

e. Mengalokasikan saham kepada pemodal jangka panjang sebagai pendukung.

Pada dasarnya, pasar modal menjembatani hubungan antara pemilik dana (investor) dan pengguna dana. Dengan demikian, dapat dikatakan bahwa pasar modal adalah wahana investasi bagi investor dan wahana sumber dana bagi penguna dana. Peranan lain dari pasar modal adalah mengumpulkan dan mengerahkan tabungan masyarakat untuk keperluan investasi. Pasar modal tergolong dalam pengertian "financial market" yang bertujuan untuk mengadakan alokasi tabungan (saving) secara efisien dari pemilik dana (saver) kepada pemakai dana terakhir (ultimate user).

Dengan meningkatnya investasi, maka kapasitas produksi akan meningkat, yang berarti menambah barang dan jasa yang diperlukan masyarakat serta memperluas lapan gan kerja. Sektor swasta menjadi lebih kompetitif dan pasar modal yang maju terutama bagian sekuritasnya memungkinkan individu, bagaimanapun kecilnya kontribusi mereka menikmati

\footnotetext{
${ }^{10} \mathrm{Ibid}$, hlm. 12
}

kemakuran karena adanya sektor swasta yang kompetitif.

Manfaat lain dari keberadaan pasar modal dapat disebutkan sebagai berikut :

a. Memperbaiki struktur permodalan perusahaan.

Perusahaan dapat meningkatkan permodalannya tidak hanya dalam bentuk pinjaman, tetapi juga bentuk ekuitas melalui penerbitan saham di pasar modal. Oleh karena itu, bagi perusahaan yang memiliki perbandingan antara modal sendiri dan hutang yang tidak seimbang (over leverage) dapat memperkecil tingkat leveragenya melalui penerbitan saham. Dengan cara ini struktur permodalan perusahaan akan semakin sehat.

b. Meningkatkan efisiensi alokasi sumber-sumber dana.

Dengan tersedianya berbagai instrumen pasar modal, perusahaan akan memperoleh alternatif yang lebih luas untuk mendapatkan dana dengan biaya yang paling rendah. Oleh karena itu, pasar modal berfungsi menciptakan pengalokasian sumber dana dengan cara yang lebih efisien.

c. Menunjang terciptanya perekonomian yang sehat.

Adanya keharusan melakukan keterbukaan di pasar modal akan melahirkan budaya fairness yang selanjutnya akan menciptakan good corporate governance di pasar modal, sehingga akan berpengaruh bagi terciptanya ekonomi yang sehat. Perusahaan publik merupakan pelopor praktik good corporate governance.

d. Meningkatkan penerimaan negara.

Melalui pasar modal, penerimaan negara melalui pemungutan pajak dapat lebih ditingkatkan. Hal ini dimungkinkan karena berkembangnya pasar modal akan memacu keterbukaan yang pada akhirnya dapat 
mendorong kepatuhan emiten sebagai wajib pajak. Di samping itu, semakin besar transaksi di bursa semakin besar pula potensi pemungutan pajak atas transaksi tersebut, khususnya pajak badan (korporasi) dan pajak perorangan.

e. Mengurangi hutang luar negeri pihak pemerintah maupun swasta.

Sudah saatnya kebutuhan akan pembiayaan pembangunan tidak hanya diperoleh dari hutang luar negeri, tetapi dapat dipenuhi melalui mobilisasi dan di pasar modal. Dengan berkurangya hutang luar negeri Pemerintah maupun pihak swasta, tekanan pada neraca pembayaran dan anggaran Pemerintah dalam memenuhi "debt service" akan dapat dikurangi.

f. Meningkatkan partisipasi masyarakat dalam pembangunan.

Melalui pasar modal, masyarakat dimungkinkan untuk dapat memiliki saham-saham perusahaan go public. Dana yang diperoleh perusahaan akan digunakan untuk pengembangan usaha yang selanjutnya akan meningkatkan produksi nasional, menambah kesempatan kerja, memperbesar penyediaan barang dan jasa yang diperlukan serta memanfaatkan sumber daya yang dimiliki oleh rumah tangga.

g. Pasar modal sebagai alternatif pembiayaan pemerintah.

Besarnya hutang luar negeri yang saat ini dimiliki pemerintah telah memberikan risiko dan kewajian bunga serta cicilan pokok yang tidak kecil. Tantangan beban fiskal pada masa yang akan datang demikian besar yang mengharuskan pemerintah mencari sumber dana baru yang tingkat risikonya relatif kecil. Kebijakan anggaran berimbang sudah ditinggalkan dan dianut sistem defisit. Defisit dimaksud dapat ditutup antara lain dengan menerbitkan obligasi pemerintah di dalam negeri melalui pasar modal. Sebagai contoh diterbitkannya obligasi pemerintah sekitar Rp. 650 trilyun dalam rangka pemberian garansi/restrukturisasi dan rekapitalisasi perbankan nasional.

Struktur pasar modal berubah cepat terutama disebabkan oleh adanya 4 (empat) faktor berikut: penemuan baru, globalisasi ekonomi, deregulasi dan bertambah pentingnya peranan investor lembaga (institutional investor).

Sebagaimana halnya suatu pasar, maka pasar modal harus efisien, dan hargaharga dari instrumen yang ada mencerminkan keadaan yang sebenarnya. Pada suatu pasar modal yang efisien, harga dari masing-masing instrumen akan menyesuaikan secara cepat terhadap informasi baru dan dengan demikian harga yang berlaku mencerminkan seluruh informasi terhadap instrumen tersebut. Pasar harus dapat merefleksikan semua informasi yang ada sehingga risiko yang mungkin timbul dapat diperkirakan.

Keterbukaan informasi merupakan latar belakang utama peraturan perundangundangan pasar modal. Harus ada keyakinan bahwa ketentuan yang berkenaan dengan kewajiban keterbukaan yang menyediakan informasi bagi para pemodal merupakan syarat utama untuk tumbuhnya pasar yang efisien. ${ }^{11}$ Blecker telah menguatkan hal ini, dikatakannya bahwa dalam rangka terlaksananya tujuan pasar modal, keputusan untuk mengadakan investasi keuangan harus didasarkan atas adanya informasi yang lengkap. ${ }^{12}$ Strong

${ }^{11}$ Irwind Friend, 1991, Economic Foundation of Stock Market Regulation, dalam James L. Bickslek (ed), Handbook of Financial Economics, North Holland Publishing Company, Amsterdam, hlm. 142

12 Robert A. Blecker, 1999, Taming Global Finance, A Better Architecture for Griwth and 
dan Walker memberikan pernyataan senada dengan menyebutkan bahwa suatu pasar modal dapat dikatakan efisien apabila surat berharga yang diperdagangkan mencerminkan semua informasi yang ada. Harga saham akan bereaksi secara cepat dan dalam trend yang tidak bias kepada adanya informasi baru. ${ }^{13}$

Frank membagi efisiensi pasar atas tiga bagian besar, yakni: efisiensi pasar bentuk lemah (weak from efficient market hypothesis/EMH), efisiensi pasar bentuk setengah kuat (semi strong EMH) dan efisiensi pasar bentuk kuat (strong EMH). ${ }^{14}$ Masing-masing bentuk dari efisiensi pasar ini ditentukan dari seberapa besar informasi-informasi yang ada di pasar modal mempengaruhi harga wajar dari suatu instrumen. Selain itu, efisiensi bagi pihak pengguna dana merupakan pertimbangan utama dalam menentukan sikap untuk mencari sumber dana, karena bagaimanapun biaya menjadi salah satu pertimbangan yang logis.

\section{Syarat Yuridis dan Prosedur Bagi Perusahaan yang akan melakukan Go Public di Pasar Modal}

Pasar modal di negara-negara maju merupakan salah satu lembaga yang diperhitungkan bagi perkembangan ekonomi negara tersebut. Oleh sebab itu negara/pemerintah mempunyai alasan untuk ikut mengatur jalannya dinamika pasar modal. ${ }^{15}$

Pasar modal Indonesia sebagai salah satu lembaga yang memobilisasi dana masyarakat dengan menyediakan sarana

Equity, Economic Policy Institute, Washington DC, hlm. 89

${ }^{13}$ Norman Strong dan Martin Walker, 1989, Information and Capital Markets, Basil Blackwell, Worcester, hlm. 122

${ }^{14}$ Eugene F. Fama, 1965, Random Walks in Stock Market Prices, Financial Analysis Journal, September/Oktober 1965

${ }^{15}$ Ibid, hlm. 7 atau tempat untuk mempertemukan penjual dan pembeli dana-dana jangka panjang yang disebut efek, dewasa ini telah merupakan salah satu pasar modal negara berkembang yang berkembang secara fantastis atau dinamik. ${ }^{16}$

Pasar modal, dalam pengertian klasik diartikan sebagai suatu bidang usaha perdagangan surat-surat berharga seperti saham, sertifikat saham, dan obligasi atau efek-efek pada umumnya. Pengertian pasar modal sebagaimana pasar umumnya yaitu merupakan tempat bertemunya penjual dan pembeli. Tetapi pasar modal berbeda dengan pasar konkret. Dalam pasar modal yang diperjualbelikan adalah modal atau dana. ${ }^{17}$ Pasar modal merupakan sarana untuk mempertemukan penawar dan peminta dana jangka panjang dalam bentuk efek.

Hugh T. Patrick dan U Tun Wai, sebagaimana dikutip Abdulbasith Anwar ${ }^{18}$ membedakan tiga arti pasar modal yaitu:

a. Arti Luas

"Pasar modal adaah keseluruhan sistem keuangan yang terorganisir, termasuk bank-bank komersil dan semua pranata di bidang keuangan, surat berharga/klaim panjang pendek primer dan yang tidak langsung".

\section{b. Arti Menengah}

"Pasar modal adalah semua pasar yang terorganisir dan lembaga-lembaga yang memperdagangkan warkat-warkat kredit (biasanya berjangka lebih dari satu tahun) termasuk saham, obligasi, pinjaman

16 Syahrir, 1995, Tinjauan Pasar Modal, Gramedia Pustaka Utama, Jakarta, hlm. 25

${ }^{17}$ Sumantoro, 1990, Pengantar tnetang Pasar Modal di Indonesia, Cetakan Pertama, Ghalia Indonesia, Jakarta, hlm. 9

${ }^{18}$ Hugh T. Patrick, U Tun Wai, "Stock and Bond Issues and Capital Market in Less Developed Countries", dalam Abdulbasith Anwar, "Pasar Modal", artikel bonus pada Manajemen dan Usahawan Indonesia, No. 9 Tahun XIX, September 1990, hlm. 12 
berjangka, hipotik, tabungan dan deposito berjangka".

\section{c. Arti Sempit}

"Pasar modal adalah tempat pasar uang terorganisir yang memperdagangkan saham dan obligasi dengan menggunakan jasa makelar dan underwriter".

Undang-Undang Nomor 8 Tahun 1995 tentang Pasar Modal (UndangUndang Pasar Modal) memberikan batasan pasar modal yaitu merupakan "kegiatan yang bersangkutan dengan penawaran umum dan perdagangan efek, perusahaan publik yang berkaitan dengan efek yang diterbitkannya, serta lembaga dan profesi yang berkaitan dengan efek. ${ }^{19}$

Batasan pengertian pasar modal yang dipergunakan adalah pengertian sebagaimana yang terdapat dalam Pasal 1 angka 13 Undang-Undang Pasar Modal. Praktek-praktek perdagangan saham seperti yang terjadi di Eropa maupun Amerika Serikat, merupakan kegiatan perusahaanperusahaan swasta yang semakin berkembang bidang usahanya. Motif utamanya adalah pemupukan bagi perusahaan kepada investor pemilih uang lebih, baik perorangan maupun lembaga. ${ }^{20}$ Dengan demikian pasar modal mempunyai peranan penting di sektor keuangan, karena pasar modal menawarkan alternatif baru bagi dunia usaha untuk memperoleh sumber pembiayaan usahanya di samping menambah alternatif baru bagi investor untuk melakukan investasi di luar investasi bidang perbankan dan bentuk-bentuk investasi yang lain. ${ }^{21}$

${ }^{19}$ Dahlan Siamat, 1995, Manajemen

Lembaga Keuangan, Intermedia, Jakarta, hlm. 400

${ }^{20}$ Dapertemen Penerangan RI, 1984, Pasar Modal Pembangunan Nasional, Jakarta, hlm. 7

${ }^{21}$ Nindyo Pramono, "Undang-Undang Pasar Modal Indonesia", Makalah Seminar Menyongsong Undang-Undang Pasar Modal, PT. Total Mega Inovatiof Progres, Jakarta, 14-15 November 1995, hlm. 1
Perkembangan kelembagaan pasar modal Indonesia masih mengalami proses pembangunan institusi (institutional building). Adanya undang-undang tidak berarti bahwa semua masalah hukum sudah teratasi. Undnag-undang hanyalah merupakan salah satu fondasi infrastruktur hukum. Oleh karena itu, hukum pasar modal sebenarnya masih dalam proses mencari bentuk.

Kegiatan pasar modal, apabila ditakar lebih merupakan objek hukum, artinya para ahli hukum perlu lebih banyak tampil. Komoditi sekuritas apakah dalam bentuk saham, obligasi, ataupun sertifikat adalah suatu kertas yang nilai intrinsiknya tidak ada, namun harganya sangat besar. Di pasar modal sebenarnya yang diperdagangkan adalah kepercayaan. Kepercayaan masyarakat pada nilai saham, benarnya laporan perusahaan, prospek keuntungan di masa mendatang, kebijaksanaan pemerintah yang mendukung pasar modal, sampai kepada proses jaminan bahwa hukum akan dipatuhi para pihak. ${ }^{22}$

Hukum yang mengatur kegiatan pasar modal mencakup ketentuan mengenai persyaratan perusahaan yang menawarkan saham atau obligasinya kepada masyarakat, ketentuan mengenai pedagang perantara, profesi penunjang, lembaga penunjang, perlindungan investor serta aturan main di pasar modal. Persyaratan tersebut dibuat dalam rangka memberikan pemahaman kepada masyarakat tentang keadaan perusahaan atau emiten. Perusahaan tersebut harus menyampaikan segala fakta material atau harus terbuka kepada masyarakat.

Perusahaan yang akan mencari dana tambahan dari masyarakat melalui pasar

\footnotetext{
22 Sumantoro, "Problema dalam Pengembangan Pasar Modal di Indonesia”, makalah seminar Masalah-Masalah Hukum di Pasar Modal Indonesia, Senat Mahasiswa Fakultas Hukum UII, Yogyakarta, 1-2 Maret 1992, hlm. 5
} 
modal, maka perusahaan tersebut harus melakukan suatu proses "going public" atau "go public". Pada hakikatnya perusahaan yang "go public" adalah perusahaan yang membuka diri terhadap keikutsertaan masyarakat dalam suatu perusahaan yang pada awalnya bersifat tertutup, baik dengan cara pemilikan maupun dengan penetapan kebijakan pengelolaan perusahaannya.

Perusahaan yang akan melakukan emisi (selanjutnya disebut emiten) harus terlebih dahulu menyampaikan Pernyataan Pendaftaran kepada Bapepam untuk menjual atau menawarkan efek kepada masyarakat dan setelah Pernyataan Pendaftaran Efektif, maka emiten dapat melakukan Penawaran Umum.

Masa penyampaian pernyataan Pendaftaran sampai Pernyataan Pendaftaran dinyatakan efektif oleh Bapepam, adalah melalui tiga proses yaitu: ${ }^{23}$

a. Pra Pendaftaran (proses ekstern)

b. Masa Tunggu (proses intern Bapepam)

c. Pasca Pernyataan Pendaftaran Efektif

Adapun penjabaran mengenai ketiga proses di atas adalah sebagai berikut:

a. Pra Pendaftaran (Pre Registration Statement)

Proses yang dilakukan oleh emiten yang akan melakukan Penawaran Umum dalam rangka "go public' meliputi: ${ }^{24}$

1) Manajemen perusahaan/emiten menetapkan terlebih dahulu rencana mencari dana melalui " $g o$ public"

2) Rencana tersebut kemudian dimintakan persetujuan pemegang

${ }^{23}$ Roger E. Meiners et.al, 1988, The Legal Environment of Business, Third Edition, West Publishing, St. Paul, hlm. 575

24 Najib, 1993, Pelaksanaan Akuisisi Perusahaan yang telah Go Public melalui Pasar Modal Indonesia : Studi kasus pada Bursa efek Jakarta, Skripsi S-1, Fakultas Hukum UII, Yogyakarta, hlm. 40-52 saham dan perubahan Anggaran Dasar dalam RUPS

3) Penunjukkan Profesi Penunjang dan Lembaga Penunjang untuk membantu menyiapkan kelengkapan dokumen

a) Penjamin Emisi (underwriter) untuk membantu emiten dalam proses emisi

b) Akuntan Publik (Auditor Independent) untuk melakukan audit atas laporan keuangan emiten untuk dua tahun terakhir dengan pendapat wajar tanpa syarat (unqualified opinion)

c) Notaris untuk melakukan perubahan Anggaran Dasar, membuat akta perjanjianperjanjian dalam rangka Penawaran Umum dan juga notulen-notulen rapat

d) Konsultan Hukum untuk memberikan pendapat dari segi hukum (legal opinion)

e) Perusahaan Penilai untuk melakukan penilaian atas aktiva yang dimiliki emiten (jika diperlukan)

f) Wali Amanat, sebagai wali bagi emiten yang akan melakukan emisi obligasi

g) Penanggung (trustee)

h) Biro Administrasi Efek (BAE)

i) Tempat Penitipan Harta (custodian)

j) Mempersiapkan kelengkapan dokumen emisi. Dokumen emisi terdiri atas: 
(1) Surat Pengantar Pernyataan Pendaftaran

(2) Prospektus final

(3) Prospektus ringkas (iklan)

(4) Iklan, brosur, edaran

(5) Dokumen lain yang diwajibkan Rencana jadwal emisi

(6) Konsep Surat Edaran

(7) Laporan keuangan

(8) Rencana penggunaan dana

(9) Proyeksi (jika tercantum dalam prospektus)

(10) Legal audit

(11) Legal opinion

(12) Riwayat Hidup Komisaris dan Direksi

(13) Perjanjian Penjaminan Emisi

(14) Perjanjian Agen Penjualan

(15) Perjanjian Penanggungan

(16) Perjanjian Perwaliamanatan

(17) Perjanjian dengan bursa efek

k) Khusus untuk penawaran obligasi atau efek lainnya yang bersifat hutang, terlebih dahulu harus memperoleh peringkat yang dikeluarkan oleh Lembaga Pemeringkat Efek

b. Masa Tunggu (Proses Intern Bapepam) atau Waiting List

Pernyataan pendaftaran yang disampaikan oleh emiten bersama Penjamin Eisi diterima oleh Bapepam. Pernyataan Pendaftaran tersebut harus memenuhi ketentuan peraturan yang dikeluarkan oleh Bapepam yaitu : Peraturan No. IX.B1.1 Lampiran Keputusan Ketua Bapepam Nomor Kep-28/PM/1994 tanggal 7 September 1991, tentang "Surat Pengantar Untuk Pernyataan Pendaftaran Dalam Rangka Penawaran Umum", Peraturan No. IX.A.1 Lampiran Keputusan Ketua Bapepam Nomor Kep-43/PM/1991 tanggal 17 Juli 1991, tentang "Ketentuan Umum Pengajuan Pernyataan Pendaftaran". Setelah Bapepam menerima Pernyataan pendaftaran tersebut, maka Bapepam melakukan: ${ }^{25}$

1) Penelaahan terhadap kelengkapan dokumen emisi

2) Menanggapi dalam waktu 45 hari

3) Mengirimkan kuesioner

4) Dengan pendapat terbatas

5) Pernyataan pendaftaran dinyatakan efektif.

c. Pasca Pernyataan Pendaftaran Efektif (Post Effective Period)

Emiten baru dapat melakukan Penawaran Umum kepada masyarakat setelah Pernyataan Pendaftaran dinyatakan efektif oleh Bapepam. Penawaran Umum untuk pertama kalinya adalah melalui Pasar Perdana. Pada Pasar Perdana ini, masyarakat baik perorangan maupun lembaga dapat memperoleh saham emiten setelah melalui tahap Pemesanan dan Penjatahan. Kelebihan pembayaran terhadap pembelian saham emiten, maka kelebihan dana tersebut akan dikembalikan (refund) oleh emiten kepada masyarakat.

Pencatatan saham di bursa efek adalah merupakan hal yang penting bagi emiten yang melakukan Penawaran Umum, sebab dengan pencatatan tersebut, maka secara resmi saham emiten dapat diperdagangkan di bursa. Ada beberapa perbedaan Persyaratan Pencatatan Saham di Bursa (dalam hal ini Bursa Efek Jakarta dan Surabaya).

Persyaratan pencatatan saham di Bursa Efek Jakarta adalah sebagai berikut:

1) Berbentuk Perseroan Terbatas

2) Pernyataan Pendaftaran Telah Efektif

3) Laporan keuangan yang telah diaudit

4) Saham yang akan dicatatkan sekurangkurangnya 1.000.000 lembar saham

5) Jumlah pemegang saham sekurangkurangnya 200 pihak

25 Najib A. Gisymar, 1999, Insider Trading dalam Transaksi Efek, Citra Aditya Bakti, Bandung, hlm. 16 
6) Pencatatan seluruh saham yang telah disetor penuh

7) Telah berdiri dan beroperasi selama 3 tahun

8) Dalam 2 tahun terakhir memperoleh laba operasional dan laba bersih

9) Total kekayaan Rp. 20.000.000.000

10) Modal sendiri Rp. 7.500 .000 .000 dan Modal disetor Rp. 2.000.000.000

Persyaratan pencatatan saham di Bursa Efek Surabaya membedakan persyaratan pencatatan saham perusahaan besar dengan menengah atau kecil. Pencatatan saham bagi perusahaan besar adalah sebagai berikut: ${ }^{26}$

1) Berbentuk Perseroan Terbatas

2) Pernyataan Pendaftaran Telah Efektif

3) Laporan keuangan yang telah diaudit

4) Saham yang akan dicatatkan sekurang-kurannya 300.000 lembar saham

5) Telah berdiri dan beroperasi selama 2 tahun

6) Dalam 2 tahun terakhir memperoleh laba bersih untuk tahun terakhir

7) Modal sendiri Rp. 1.500.000.000 dan modal disetor Rp. 1.000.000.000

Sedangkan persyaratan pencatatan saham perusahaan menengah kecil adalah sebagai berikut:

1) Pernyataan Pendaftaran Telah Efektif Emiten harus berbadan hukum, berbentuk Perseroan Terbatas

2) Laporan keuangan telah diperiksa oleh Akuntan yang terdaftar di Bapepam dengan pendapat Wajar Tanpa Syarat untuk tahun buku akhir

3) Emiten memiliki sekurangkurangnya dua orang Komisaris dan tiga orang Direksi yang memiliki reputasi yang baik

${ }^{26}$ Departemen Keuangan RI - Bapepam, t.th., Penawaran Umum (Public Offering), brosur, t. hlm
4) Didukung oleh sekurang-kurangnya dua market maker untuk tahun pertama.

5) Dalam hal emiten menderita kerugian, maka besarnya jumlah kerugian tersebut tidak boleh lebih dari 405 dari modal disetor

6) Emiten diwajibkan untuk mencatatkan seluruh saham yang telah disetor penuh, sepanjang tidak bertentangan dengan ketentuan tentang presentasi kepemilikan saham oleh pemodal asing

7) Memenuhi persyaratan administrasi serta semua prosedur PT. Bursa Efek Surabaya

Pencatatan obligasi di bursa efek harus memenuhi beberapa persyaratan yang ditentukan oleh pengelola bursa efek. Persyaratan pencatatan obligasi di PT. Bursa Efek Jakarta adalah sebagai berikut:

1) Berbentuk Perseroan Terbatas

2) Pernyataan Pendaftaran telah Efektif

3) Laporan keuangan telah diperiksa oleh Akuntan dengan pendapat Wajar Tanpa Syarat untuk tahun buku terakhir

4) Nilai Nominal Obligasi minimal Rp. 25.000.000.000,-

5) Rentang waktu efektif Pernyataan Pendaftaran dan Pencatatan tidak lebih dari 6 bulan dan sisa jatuh tempo minimal 4 tahun

6) Telah berdiri dan beroperasi minimal 3 tahun

7) Telah memperoleh laba operasional dalam 2 tahun terakhir

8) Komisaris dan direksi memiliki reputasi yang baik.

Persyaratan pencatatan obligasi di PT. Bursa Efek Surabaya untuk perusahaan besar adalah sebagai berikut:

1) Berbentuk Perseroan Terbatas

2) Pernyataan Pendaftaran telah Efektif 
3) Laporan keuangan telah diperiksa oleh Akuntan dengan pendapat Wajar Tanpa Syarat untuk tahun buku terakhir

4) Nilai Nominal Obligasi minimal Rp. 3.000.000.000,-

5) Rentang waktu efektif Pernyataan Pendaftaran dan Pencatatan maksimal 6 bulan dan sisa jatuh tempo minimal 1 tahun

6) Telah berdiri dan beroperasi minimal 2 tahun

7) Komisaris dan direksi memiliki reputasi yang baik

Sedangkan persyaratan pencatatan obligasi untuk perusahaan menengah dan kecil adalah sebagai berikut:

1) Pernyataan Pendaftaran telah Efektif

2) Emiten harus berbadan hukum, berbentuk Perseroan Terbatas

3) Laporan keuangan telah diperiksa oleh Akuntan yang terdaftar di Bapepam dengan pendapat Wajar Tanpa Syarat untuk tahun buku akhir

4) Emiten memiliki sekurangkurangnya dua orang komisaris dan tiga orang direksi yang memiliki reputasi baik

5) Didukung oleh sekurang-kurangnya dua market maker untuk tahun pertama

6) Dalam hal emiten menderita kerugian, maka besarnya jumlah kerugian tersebut tidak boleh lebih dari $25 \%$ a dari modal disetor

7) Dalam hal emiten tersebut adalah bank, maka harus ada rekomendasi dari Bank Indonesia yang menyatakan bahwa Bank tersebut adalah sehat

8) Pernyataan dalam huruf a di atas tidak berlaku bagi obligasi Pemerintah, Obligasi Pemerintah Daerah dan obligasi lain yang dicatatkan atas permintaan Menteri Keuangan

\section{KESIMPULAN DAN SARAN}

Berdasarkan hasil penelitian dan pembahasan Aspek Yuridis Pasar Modal Sebagai Sarana Pembiayaan dan Pengembangan Perusahaan, maka dapat ditarik kesimpulan yang merupakan jawaban terhadap permasalahan dalam penelitian ini sebagai berikut:

1. Guna memenuhi kebutuhan perusahaan akan dana sebagai sarana pembiayaan dan pengembangan perusahaan dapat dilakukan melalui berbagai macam pilihan pembiayaan perusahaan dan salah satu alternatif pembiayaan perusahaan tersebut dapat dilakukan dengan cara mencari pihak lain untuk ikut menanamkan modalnya pada perusahaan tersebut. Pasar Modal mempunyai peran yang cukup strategis sebagai sarana pembiayaan dan pengembangan perusahaan. Hal ini dapat dilakukan dengan menjual sebagian kepemilikan atas perusahaan kepada masyarakat luas dengan cara penawaran umum (go public) melalui pasar modal.

2. Penawaran umum perdana yang dilakukan oleh perusahaan melalui pasar modal dapat menjadikan perusahaan tersebut menerima uang tunai dari masyarakat yang selanjutnya dapat dipergunakan oleh perusahaan untuk pembiayaan dan pengembangan perusahaan. Penawaran umum perdana tersebut harus dilakukan sesuai dengan syarat yuridis dan prosedur yang telah diatur dalam peraturan perundangundangan yang berlaku. Perusahaan yang akan mencari dana tambahan dari masyarakat melalui pasar modal, 
maka perusahaan tersebut harus melakukan suatu proses "going public" atau "go public". Pada hakikatnya perusahaan yang "go public" adalah perusahaan yang membuka diri terhadap keikutsertaan masyarakat dalam suatu perusahaan yang pada awalnya bersifat tertutup, baik dengan cara pemilikan maupun dengan penetapan kebijakan pengelolaan perusahaannya.

\section{DAFTAR PUSTAKA}

Asril Sitompul, 1996, Pasar Modal, Penawaran Umum dan Permasalahannya, Citra Aditya Bakti, Bandung

Dahlan Siamat, 1995, Manajemen Lembaga Keuangan, Intermedia, Jakarta

Dapertemen Penerangan RI, 1984, Pasar Modal Pembangunan Nasional, Jakarta

Departemen Keuangan RI - Bapepam, t.th, Penawaran Umum (Public Offering), brosur

Eugene F. Fama, 1965, Random Walks in Stock Market Prices, Financial Analysis Journal, September/Oktober 1965

Frank J. Fabozzi dan Madigliani Franco, 1992, Capital Market : Institutions and Intrument, Prentice hall Inc., A

Simon \& Schuter Company Engk Wood Cliffs, New Jersey

Hugh T. Patrick, U Tun Wai, "Stock and Bond Issues and Capital Market in Less Developed Countries", dalam Abdulbasith Anwar, "Pasar Modal", artikel bonus pada Manajemen dan Usahawan Indonesia, No. 9 Tahun XIX, September 1990

Irwind Friend, 1991, Economic Foundation of Stock Market Regulation, dalam
James L. Bickslek (ed), Handbook of Financial Economics, North Holland Publishing Company, Amsterdam

Jasso Winarto (ed), 1997, Pasar Modal Indonesia, Pustaka Sinar Harapan, Jakarta

John Fingleton, 1992, The Internalization of Capital Markets and the Regulatory Response, Graham \& Tratman, London

Jusuf Anwar, 2005, Pasar Modal Sebagai Sarana Pembiayaan dan Investasi, Alumni, Bandung

Michael P. Mc Lindon, 1996, Proegen, Connecticut

Najib A. Gisymar, 1999, Insider Trading dalam Transaksi Efek, Citra Aditya Bakti, Bandung

Najib, 1993, Pelaksanaan Akuisisi Perusahaan yang telah Go Public melalui Pasar Modal Indonesia : Studi kasus pada Bursa efek Jakarta, Skripsi S1, Fakultas Hukum UII, Yogyakarta

Nindyo Pramono, "Undang-Undang Pasar Modal Indonesia", Makalah Seminar 
Menyongsong Undang-

Undang Pasar Modal, PT.

Total Mega Inovatiof Progres,

Jakarta, 14-15 November 1995

Norman Strong dan Martin Walker, 1989, Information and Capital Markets, Basil Blackwell, Worcester

Robert A. Blecker, 1999, Taming Global Finance, A Better Architecture for Griwth and Equity, Economic Policy Institute, Washington DC

Roger E. Meiners et.al, 1988, The Legal Environment of Business, Third Edition, West Publishing, St. Paul

Sumantoro, 1990, Pengantar tnetang Pasar Modal di Indonesia, Cetakan Pertama, Ghalia Indonesia, Jakarta

Sumantoro, 1992, "Problema dalam Pengembangan Pasar Modal di Indonesia", makalah seminar Masalah-Masalah Hukum di Pasar Modal Indonesia, Senat Mahasiswa Fakultas Hukum UII, Yogyakarta, 1-2 Maret 1992

Syahrir, 1995, Tinjauan Pasar Modal, Gramedia Pustaka Utama, Jakarta 